\title{
Kecepatan Siswa Menyelesaikan Soal Cerita Matematika Melalui Model Problem BaSEd LEARNing Di SMK Pembangunan TanjungPinang
}

\author{
Linda Jasira1, Rezky Ramadhona ${ }^{2}$ dan Linda Rosmery Tambunan ${ }^{3}$ \\ 1,2,3Pendidikan Matematika, FKIP Universitas Maritim Raja Ali Haji \\ Jalan Raya Dompak Tanjungpinang, 29124, Provinsi Kepulauan Riau, Indonesia \\ 1lindajasira7@gmail.com
}

\begin{abstract}
Abstrak
Penelitian ini merupakan Penelitian Tindakan Kelas yang bertujuan untuk meningkatkan kecepatan siswa dalam menyelesaikan soal cerita sistem persamaan linear tiga variabel melalui model pembelajaran Problem Based Learningdi kelas X SMK Pembangunan Tanjungpinang. Subjek dalam penelitian ini adalah siswa kelas $X$ di SMK Pembangunan Tanjungpinang yang berjumlah 27 siswa. Penelitian ini dilaksanakan dalam 2 siklus, yakni siklus pertama terdiri dari 3 kali pertemuan dan siklus kedua terdiri dari 3 kali pertemuan. Instrumen yang digunakan dalam penelitian ini adalah tes untuk mengukur kecepatan keterampilan siswa dalam menyelesaikan soal cerita sistem persamaan linear tiga variabel, lembar observasi pelaksanaan pembelajaran, pencapaian alokasi waktu dan catatan lapangan. Data dari hasil tes, observasi dan catatan lapangan dari semua data yang diperoleh tersebut dianalisis secara deskriptif kualitatif.Hasil penelitian menunjukkan bahwa kecepatan siswa dalam menyelesaikan soal cerita sistem persamaan linear tiga variabel siswa kelas $X$ SMK Pembangunan Tanjungpinang mengalami peningkatan dari siklus I ke siklus II setelah dilaksanakan pembelajaran melalui model pembelajaran Problem Based Learning. Dengan demikian, siswa mempunyai respon yang positif terhadap pembelajaran matematika melalui model Problem Based Learning dalam upaya meningkatkan kecepatan siswa dalam menyelesaikan soal cerita sistem persamaan linear tiga variabel.

Kata Kunci: Kecepatan Menyelesaikan Soal Matematika, Soal Cerita Matematika, Problem Based Learning
\end{abstract}

\begin{abstract}
This research is a Classroom Action Research that aims to improve the speed of students in solving the problem story system of linear equations of three variables through the model of Problem Based Learning in class X SMK Pembangunan Tanjungpinang. Subjects in this study were the students of class $X$ in vocational development Tanjungpinang totaling 27 students. This research is conducted in 2 cycles, in the first cycle consists of 3 meetings and the second cycle consists of 3 meetings. The instrument used in this study is a test to measure the speed of the students' skills in solving the story problem of linear equations system of three variables, observation sheet of learning implementation, achievement of time allocation and field notes. Data from the test results, observations and field notes of all the data obtained are analyzed descriptively qualitatif. Research results show that the speed of students in solving the problem story system of linear equations of three variables of students' class X SMK Development Tanjungpinang increased from cycle I to cycle II after implemented learning through the model of learning Problem Based Learning. Thus, students have a positive response to the learning of mathematics through the model of Problem Based Learning in an effort to increase the student's speed in solving the problem story system of linear equations of three variables.

Keyword: Speed Solving Mathematics Problem, Mathematical Problem Story, Problem Based Learning
\end{abstract}


http://journal.institutpendidikan.ac.id/index.php/mosharafa

\section{Pendahuluan}

Pada umumnya para siswa menganggap bahwa matematika merupakan mata pelajaran yang sulit dibanding mata pelajaran lainnya. Terbukti pada setiap pembahasan soal yang menyangkut kehidupan sehari-hari, terlebih soal yang tersaji dalam bentuk soal cerita maka sebagian besar siswa tidak dapat menyelesaikan dengan benar dan memerlukan waktu yang lama. Hal ini disebabkan karena siswa tidak memahami maksud soal, lemah dalam penguasaan bahasa atau belum mengetahui prosedur rutin yang seharusnya digunakan untuk menyelesaikan soal tersebut.

Soal cerita bagi hampir sebagian besar siswa dianggap sebagai suatu masalah yang sering mereka jumpai dalam setiap pembelajaran. Menurut Raharjo dan Astuti (2011:8) menjelaskan bahwa bentuk soal yang digunakan untuk mengukur kemampuan siswa dalam pembelajaran matematika dapat berupa soal cerita atau soal non cerita. Soal cerita yang dimaksud berkaitan erat dengan masalah yang ada dalam kehidupan sehari-hari , sehingga yang dimaksud dengan soal cerita adalah soal matematika yang terkait dengan kehidupan sehari-harl untuk dicari penyelesaiannya menggunakan kalimat matematika yang memuat bilangan, operasi hitung $(+,-, \times, \div)$, dan relasi $(=,<,>, \leq, \geq)$."

Khususnya pada materi yang akan di bahas pada penelitian ini yaitu mengenai Sistem Persamaan Linear Tiga Variabel. Dimana materi Sistem Persamaan Linear Tiga Variabel, pada umumnya kebanyakan menyajikan soal-soal dalam bentuk cerita. Berdasarkan wawancara peneliti dengan guru matematika di kelas $X$ SMK Pembangunan diperoleh informasi bahwa penyebab siswa mengalami kesulitan dalam menyelesaikan soal SPLTV adalah siswa belum mampu memahami maksud dari soal yang diberikan dan belum mampu mengubah soal cerita ke dalam bentuk model matematika, kemudian pada bagian memahami makna kalimat dari soal dan penggunaan langkahlangkah/prosedur penyelesaian soal materi Sistem Linear Persamaan Linear Tiga Variabel masih sangat rendah dan siswa tidak bisa mengalokasikan waktu pada saat penyelesaian. Masalah kecepatan siswa yang belum bisa mengalokasi waktu adalah siswa masih memerlukan waktu yang cukup lama pada saat memodelkan dari soal cerita ke model matematika SPLTV maupun menyelesaikan soal cerita dengan langkah yang prosedur atau sistematis sesuai dengan materi SPLTV.

Adapun kesalahan tersebut yang membuat siswa memerlukan waktu yang lama seperti kesalahan menentukan apa yang diketahui, kesalahan menentukan apa yang ditanya, kesalahan menentukan pemisalan variable, kesalahan membuat model matematika, kesalahan dalam menuliskan metode penyelesaian, kesalahan menentukan langkah-langkah dalam penyelesaian, dan kesalahan dalam memperoleh hasil akhir. Beberapa kesalahan lain yang sering terjadi sesuai penelitian Silitonga dan Febrian (2016) yang dilakukan adalah kesalahan data dan 
prosedur sehingga dapat menghambat penemuan solusi masalah.

Sebagaimana didefinisikan oleh Lester \& Kehle (2003) dalam (Febrian, 2016) pemecahan masalah matematika merupakan proses berpikir dimana pemecah masalah mencoba mendekati situasi masalah dengan menggunakan pengetahuan matematika yang pernah diperoleh sebelumnya. Hal ini senada dengan pendapat (Febrian, 2016) yang menyatakan bahwa pemecahan masalah membutuhkan pengetahuan awal sesuai dengan karakter masalah yang dihadapi. Kemampuan pemecahan masalah merupakan bagian dari kurikulum matematika yang sangat penting karena dalam proses pembelajaran maupun penyelesaiannya siswa dimungkinkan memperoleh pengalaman menggunakan pengetahuan dan keterampilan yang sudah dimiliki untuk diterapkan pada pemecahan masalah yang bersifat rutin. (Yusri, 2018).

Mengingat demikian besarnya peranan matematika dalam kehidupan sehari-hari dan pengembangan disiplin ilmu lainnya, maka kemampuan siswa dalam memecahkan masalah matematika serta kecepatan menyelesaikan soal cerita perlu ditingkatkan. Dengan meningkatkan kecepatan menyelesaikan soal cerita para siswa menjadi meningkat dalam hal mengumpulkan informasi yang relevan, menganalisis informasi dan berani mengambil keputusan yang tepat serta menyadari betapa pentingnya meneliti kembali hasil yang diperoleh.
Sedangkan proses pembelajaran di kelas, guru masih menerapkan pembelajaran seperti pada umumnya yang bersifat konvensional. Tampak bahwa pembelajaran belum berpusat pada siswa (student centered learning). Sedangkan berdasarkan makna pembelajaran adalah segala upaya yang dilakukan oleh pendidik agar terjadi proses belajar pada diri peserta didik (Dr. M. Sobry Sutikno., 2014: 12). Pembelajaran lebih menekankan pada cara-cara untuk mencapai tujuan dan berkaitan dengan berbagai cara mengorganisasikan isi pembelajaran, menyampaikan isi pembelajaran, dan mengelola pembelajaran. Suatu proses pembelajaran dikatakan sukses apabila seorang guru dan sejumlah siswa mampu melakukan interaksi komunikatif terhadap berbagai persoalan pembelajaran di kelas dengan cara melibatkan siswa sebagai komponen utamanya. Model pembelajaran yang digunakan masih terbatas pada model ceramah sehingga siswa tampak pasif selama proses pembelajaran berlangsung. Sehingga tidak ada diskusi antara siswa yang satu dengan siswa yang lainnya. Hal ini menjadi pendukung kurangnya kemampuan siswa dalam memecahkan masalah.

Hal ini ditekankan oleh Sugondo (Syamsuddin, 2003: 226) bahwa latihan memecahkan soal cerita penting bagi perkembangan proses secara sistematis, menghargai matematika sebagai alat yang dibutuhkan untuk memecahkan masalah, dan akhirnya anak akan dapat menyelesaikan masalah yang lebih rumit. 
Dalam masalah ini, tidak hanya alternatif pemecahan masalah untuk keterampilan saja yang diperlukan, namun masalah yang diteliti.

dibutuhkan kemampuan lain seperti

Dalam penelitian ini, peneliti akan penalaran matematika. Dengan demikian, mendeskripsikan kecepatan siswa dalam pemecahan masalah atau soal cerita menyelesaikan soal cerita pada materi dengan menggunakan model Problem sistem persamaan linear tiga variabel kelas Based Learning (PBL) ini diharapkan siswa $X$ menggunakan model pembelajaran terampil dalam menyelesaikan permasalahan terkait soal-soal cerita yang menyangkut kehidupan sehari - hari khususnya pada materi Sistem Persamaan Linear Tiga Variabel. Permasalahan permasalahan tersebut mengenai angka dan bilangan, umur, uang, investigasi dan bisnis, ukuran, sembako dan lain - lain.

\section{Metode}

Penelitian ini merupakan Penelitian Tindakan Kelas (PTK) yang dimaksudkan untuk memaksimalkan hasil penelitian. Pemilihan pendekatan tersebut disebabkan karena dengan menggunkan metode penelitian tindakan kelas peneliti dapat secara langsung memberikan Problem Based Learning (PBL) di SMK Pembangunan Tanjungpinang.

Model penelitian yang di gunakan dalam Penelitian Tindakan Kelas ini adalah model yang dikembangkan oleh Kemmis \& Mc. Taggart. Siklus tidak hanya belangsung satu kali, melainkan beberapa kali sehingga tujuan pembelajaran dapat lebih bermakna. Menurut Kemmis \& Mc. Taggart dalam Sukardi (2013) terdapat empat komponen penelitian tindakan kelas, yaitu perencanaan, pelaksanaan, observasi dan refleksi dalam suatu sistem spiral yang saling terkait antara langkah yang satu dengan langkah yang langkah berikutnya (Sukardi,2013). 


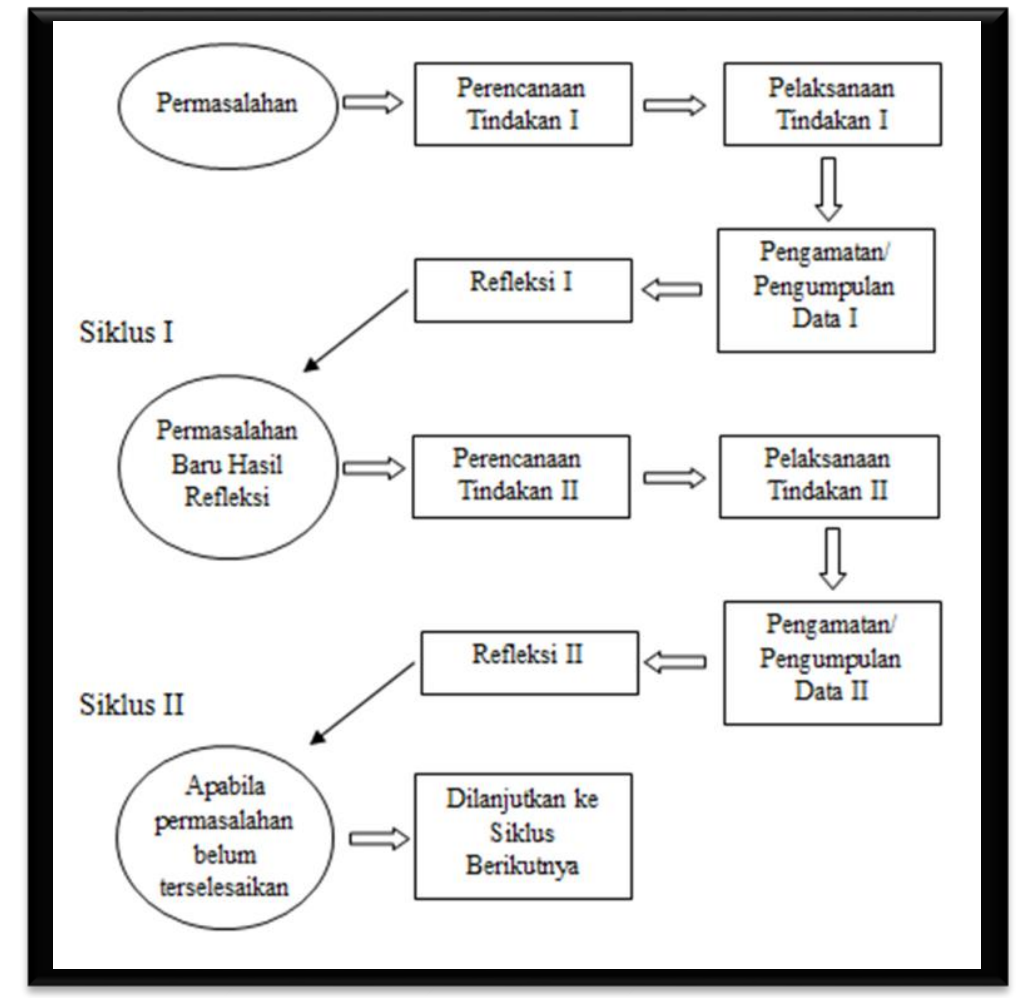

Gambar 1. Penelitian Tindakan Kelas Model Kemmis \& Taggart

Adapun prosedur penelitian tindakan kelas yang akan dilakukan adalah sebagai berikut:

1. Penyusunan Rencana Pelaksanaan Pembelajaran (RPP) tentang materi Sistem Persamaan Linear Tiga Variabel yang akan diajarkan dengan menggunakan model pembelajaran Problem Based Learning yang disusun dengan pertimbangan dosen pembimbing dan guru matematika.

2. Persiapan model yang akan digunakan dalam pembelajaran. Model tersebut yaitu Problem Based Learning sesuai dengan fasenya.

3. Kemudian persiapan Lembar Kerja Siswa (LKS) yang berisi soal cerita Sistem Persamaan Linear Tiga Variabel untuk melatih keterampilan siswa dalam menyelesaikan soal.

4. Penetapan pencapaian alokasi waktu untuk menyelesaikan soal cerita.

5. Persiapan dan penyusunan lembar kisi - kisi soal tes siklus I lembar soal tes uraian siklus I dan lembar jawaban soal tes siklus I.

6. Penyusunan lembar observasi yang digunakan dalam pembelajaran untuk setiap siklus diantaranya lembar observasi keterlaksanaan pembelajaran siswa dan lembar observasi keterlaksanaan guru mengajar.

7. Pemilihan ketua kelompok

Pemilihan ketua kelompok sesuai dengan kriteria: 
a. Dapat diterima (disetujui) oleh siswa lain, sehingga siswa tidak takut atau enggan untuk bertanya kepadanya.

b. Dapat menerangkan bahan atau materi yang diperlukan oleh siswa.

c. Tidak tinggi hati, kejam, atau keras hati terhadap sesame kawan.

d. Mempunyai daya kreatifitas yang cukup untuk memberikan bimbingan yaitu dapat menerangkan pelajaran kepada kawannya

8. Pembagian Kelompok

Setiap kelompok terdiri dari 6-7 peserta didik di setiap kelompoknya. Dalam setiap kelompok terdapat satu peserta didik yang menjadi ketua. Anggota kelompok lain akan dipilih berdasarkan siswa yang mempunyai prestasi rendah maupun tinggi.

Subjek penelitian ini adalah siswa kelas X SMK Pembangunan Tanjungpinang yang berjumlah 27 siswa.

Aspek yang di nilai untuk mengetahui kecepatan siswa dalam menyelesaikan soal cerita SPLTV dalam penelitian ini adalah kecepatan siswa dalam mendeskripsikan penjelasan ditulis secara matematis serta tersusun secara logis dan sistematis, menggunakan metode secara lengkap serta mendapatkan solusi yang benar, dan membuat model matematika dengan benar, kemudian melakukan perhitungan dengan tepat serta mendapatkan solusi yang benar dan lengkap.
Penelitian ini dinilai dan dikatakan berhasil apabila memenuhi ketercapaian parameter sebagai berikut:

1. Siswa dapat menyelesaikan soal-soal tes dengan baik sesuai waktu yang di alokasikan untuk setiap soal yaitu kategori A kurang dari 10 menit, kategori B yaitu 11-15 menit dan kategori $C$ yaitu lebih dari 15 menit.

2. Minimal $75 \%$ dari jumlah siswa dapat mencapai Kriteria Ketuntasan Minimal (KKM) sebesar 70 dengan menggunakan skor yang diperoleh siswa melalui soal tes kecepatan siswa dalam menyelesaikan soal cerita.

Dalam penelitian ini, data dikumpulkan melalui tes tertulis dan observasi.

Tes yang diberikan merupakan tes tertulis bentuk uraian. Tes ini terdiri dari dua buah soal yang harus dijawab siswa sesuai dengan kompetensi dan indikator kecepatan siswa dalam menyelesaikan soal cerita terkait materi sistem persamaan linear tiga variabel. Tes ini dikerjakan siswa secara individu dengan berdasarkan waktu yang telah di tetapkan dalam menyelesaikan soal cerita.

Observasi di lakukan untuk memperoleh data aktifitas siswa sebagai selama pembelajaran.

Setelah tes dilaksanakan, maka didapatlah skor masing-masing siswa. Skor tersebut dijumlahkan lalu di analisis, langkah untuk menganalisis data hasil tes tertulis adalah menentukan nilai tes siswa dan menentukan kategori kecepatan siswa dalam menyelesaikan soal cerita. 
Tabel 1.

Kategori Keterampilan Menyelesaikan Soal Cerita SPLTV

\begin{tabular}{|c|c|c|c|}
\hline Skor & Teks Tertulis/Kata & Metode Persamaan & Ekspresi Matematika/Persamaan \\
\hline 0 & & Tidak ada jawaban & \\
\hline 1 & $\begin{array}{l}\text { Penjelasan ditulis secara } \\
\text { matematis akan tetapi } \\
\text { masih salah. }\end{array}$ & $\begin{array}{l}\text { Tidak menggunakan } \\
\text { metode, } \\
\text { mendapatkan solusi. }\end{array}$ & $\begin{array}{l}\text { Membuat model matematika namun } \\
\text { masih salah. }\end{array}$ \\
\hline 2 & $\begin{array}{l}\text { Penjelasan ditulis secara } \\
\text { matematis akan tetapi tidak } \\
\text { lengkap. }\end{array}$ & $\begin{array}{l}\text { Menggunakan metode, akan } \\
\text { tetapi tidak lengkap. }\end{array}$ & $\begin{array}{l}\text { Membuat model matematika dengan } \\
\text { benar, namun terdapat kesalahan } \\
\text { dalam perhitungan. }\end{array}$ \\
\hline 3 & $\begin{array}{l}\text { Penjelasan ditulis secara } \\
\text { matematis dan logis, akan } \\
\text { tetapi tidak tersusun secara } \\
\text { sistematis. }\end{array}$ & $\begin{array}{l}\text { Menggunakan metode } \\
\text { secara lengkap namun salah } \\
\text { dalam mendapatkan solusi. }\end{array}$ & $\begin{array}{l}\text { Membuat model matematika dengan } \\
\text { benar, kemudian melakukan } \\
\text { perhitungan dengan tepat, namun } \\
\text { salah dalam mendapatkan solusi. }\end{array}$ \\
\hline 4 & $\begin{array}{l}\text { Penjelasan ditulis secara } \\
\text { matematis serta tersusun } \\
\text { secara logis dan sistematis. }\end{array}$ & $\begin{array}{lr}\text { Menggunakan metode } \\
\text { secara lengkap serta } \\
\text { mendapatkan solusi yang } \\
\text { benar }\end{array}$ & $\begin{array}{l}\text { Membuat model matematika dengan } \\
\text { benar, kemudian melakukan } \\
\text { perhitungan dengan tepat serta } \\
\text { mendapatkan solusi yang benar dan } \\
\text { lengkap. }\end{array}$ \\
\hline
\end{tabular}

Tabel 2.

Pencapaian Alokasi Waktu untuk Menyelesaikan Soal Cerita

\begin{tabular}{|cc|}
\hline Alokasi Waktu & Keterangan \\
\hline A & $\leq 10$ menit \\
\hline B & $11-15$ menit \\
\hline C & $>15$ menit \\
\hline
\end{tabular}

\section{Hasil dan Pembahasan}

Penelitian ini dilaksanakan mulai tanggal 1Mei 2017 hingga 22 Mei 2017 di kelas X SMK Pembangunan Tanjungpinang. Penelitian ini dilaksanakan sebanyak 2 siklus dengan 6 kali pertemuan. Siklus I dilaksanakan sebanyak 2 kali pertemuan kegiatan pembelajaran dan 1 pertemuan terakhir untuk tes dan siklus ॥ dilaksanakan sebanyak 2 kali pertemuan kegiatan pembelajaran dan 1 pertemuan terakhir untuk tes kecepatan keterampilan siswa dalam menyelesaikan soal cerita.

Pembelajaran dilaksanakan sesuai langkah-langkah pada model pembelajaran Problem Based Learning yaitu mengorientasikan siswa pada masalah, mengorganisasikan siswa untuk belajar, membimbing pengalaman individu/kelompok, mengembangkan dan menyajikan hasil karya, menganalisis dan mengevaluasi proses pemevahan masalah. Selama proses pembelajaran berlangsung, guru menggunakan lembar kerja siswa (LKS) untuk mengefektifkan proses pembelajaran.

Berdasarkan hasil siklus I dan data observasi siswa padas siklus I diperoleh bahwa hanya beberapa siswa yang mengerjakan soal dan mengikuti pembelajaran dengan langkah Problem Based Learning. Masalah ini dikarenakan mereka kesulitan dalam memahami soal. Faktor yang memungkinkan menjadi penyebab kesulitan siswa adalah pemahaman atau penguasaan bahasa masih sangat kurang. Jika siswa dapat memahami maksud soal, maka mereka dapat menangkap maksud soal kemudian 


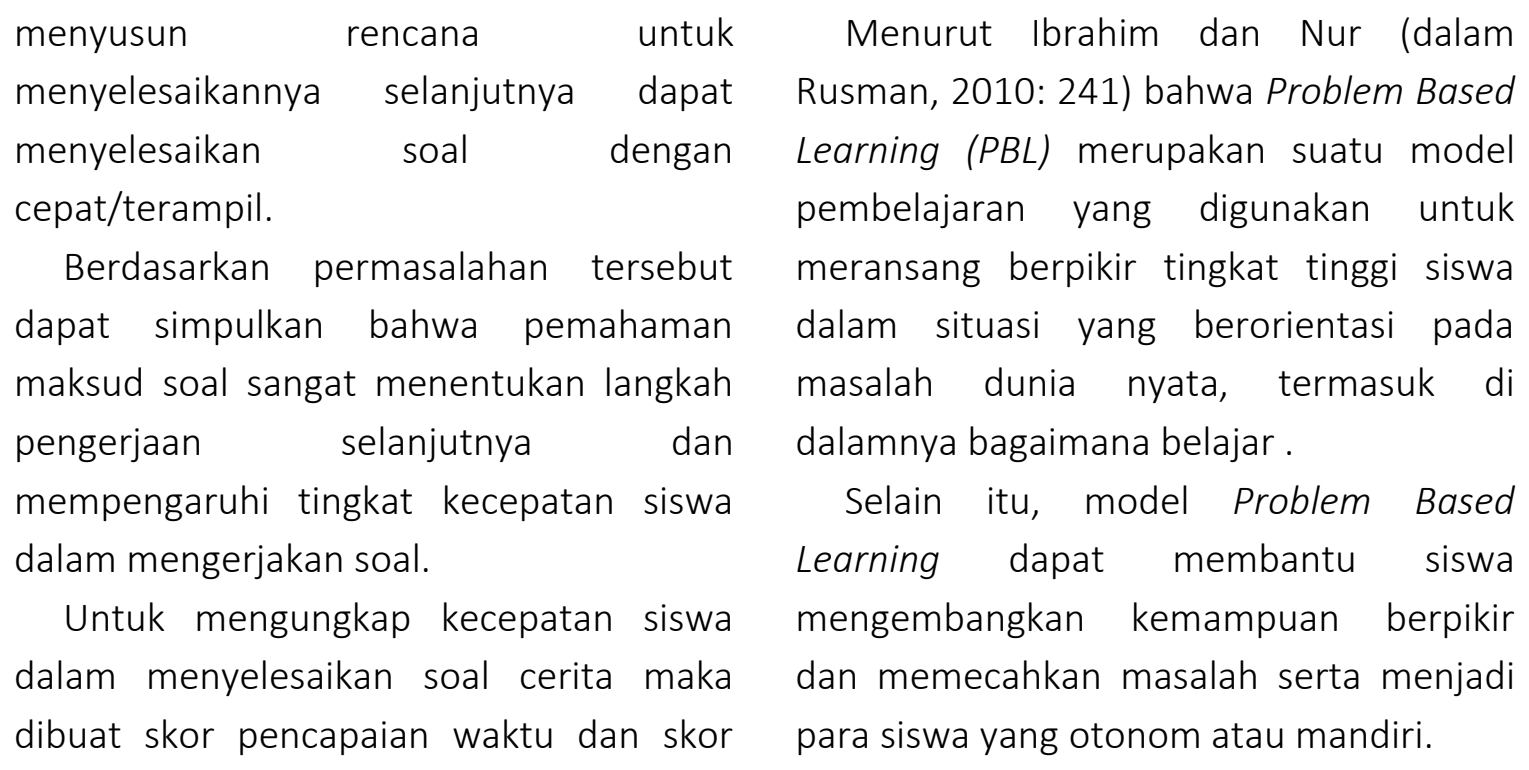
nilai. Dari kedua gabungan skor tersebut dapat diketahui tingkat kecepatan siswa dalam menyelesaikan setiap soal.

Sesuai dengan data hasil siklus I diperoleh tingkat kecepatan siswa dalam menyelesaikan soal cerita adalah 6,37.

Pada siklus II kecepatan siswa dalam menyelesaikan soal cerita menggunakan model pembelajaran Problem Based Learning pada umumnya sudah meningkat. Hal ini terlihat dari hasil pekerjaan dari jawaban yang sudah tersusun secara urut dan sistematis dan di lihat dari pencapaian alokasi waktu untuk menyelesaikan soal cerita.

Hasil akhir siklus II diperoleh tingkat kecepatan siswa dalam menyelesaikan soal cerita dengan model Problem Based Learning adalah sebesar 7,68

Berdasarkan berbagai penjelasan di atas, maka dapat disimpulkan bahwa pembelajaran menggunakan model Problem Based Learning mampu meningkatkan kecepatan siswa dalam menyelesaikan soal cerita.

\section{Penutup}

Berdasarkan hasil penelitian kecepatan siswa dalam menyelesaikan soal cerita yang diperoleh siswa kelas $X$ SMK Pembangunan Tanjungpinang terjadi peningkatan pada setiap siklus setelah diterapkan model Problem Based Learning. Peningkatan kecepatan siswa dalam menyelesaikan soal cerita tersebut dapat diuraikan sebagai berikut: 1) Sebanyak 17 siswa atau 62,96 \% dari jumlah siswa mengalami peningkatan skor pada aspek penjelasan ditulis secara sistematis serta tersusun secara logis dan sistematis; 2) Sebanyak 20 siswa atau 74,07 \% dari jumlah siswa mengalami peningkatan skor pada aspek menggunakan metode secara lengkap serta mendapatkan solusi yang benar; 3) Sebanyak 21 siswa atau 77,78 \% dari jumlah siswa mengalami peningkatan skor pada aspek membuat model matematika dengan benar, kemudian melakukan perhitungan dengan tepat serta mendapatkan solusi yang benar dan 
lengkap; dan 4) Peningkatan rata-rata nilai tes dari siklus I ke siklus II yaitu dari 6,37 menjadi 7,68.

Berdasarkan kesimpulan penelitian dapat ditarik implikasi teoriitis dan praktis dan implikasi praktis sebagai berikut: 1) Pada penelitian penerapan model pembelajaran Problem Based Learning dalam meningkatkan keterampilan menyelesaikan soal cerita materi sistem persamaan linear tiga variabel siswa kelas $X$ Sekolah Menengah Kejuruan Pembangunan Tanjungpinang tahun pelajaran 2016/2017 diharapkan dapat bermanfaat sebagai sumbangan pemikiran dalam bidang pendidikan khususnya pada mata pelajaran matematika yang dapat meningkatkan kualitas pendidikan; 2) Bagi Peneliti, dengan adanya penelitian penerapan model pembelajaran Problem Based Learning dalam meningkatkan keterampilan menyelesaikan soal cerita materi sistem persamaan linear tiga variabel siswa kelas X Sekolah Menengah Kejuruan Pembangunan Tanjungpinang diharapkan dapat menambah pengetahuan dan pengalaman mengajar dengan menerapkan model pembelajaran Problem Based Learning; 3) Bagi Siswa, penerapan model pembelajaran Problem Based Learning dapat meningkatkan keterampilan menyelesaikan soal cerita materi sistem persamaan linear tiga variabel siswa. Selain itu siswa akan lebih terdorong untuk menyelesaikan suatu permasalahan matematika dengan melakukan langkah - langkah penyelesaian masalah. Dengan menerapkan model pembelajaran Problem Based Learning juga dapat memberikan variasi pembelajaran dalam kelas; 4) Bagi guru, penelitian ini dapat dijadikan acuan dalam menggunakan berbagai model, metode dan teknik serta pendekatan dalam proses pembelajaran.

Berdasarkan hasil penelitian. Diambil saran sebagai berikut: 1) Guru disarankan melaksanakan Penelitian Tindakan Kelas (PTK) agar lebih mengenal secara mendalam permasalahan dalam proses pembelajaran untuk meningkatkan mutu pendidikan, sehingga prestasi belajar siswa bisa meningkat; 2) Dalam proses pembelajaran hendaknya guru dapat memberikan variasi model pembelajaran, dan dalam memilih model, metode dan pendekatan hendaknya memilih yang tepat dan sesuai dengan karakteristik siswa dengan lebih memperhatikan materi yang akan diajarkan; 3) Kepada para peneliti yang berminat melaksanakan Problem Based Learning. Hendaknya mempertimbangkan materi yang sesuai dengan pembelajaran ini, dan hendaknya membuat persiapan yang matang agar proses pembelajaran berjalan dengan lancer; 4) Pembelajaran matematika dengan menerapkan model pembelajaran Problem Based Learning tidak hanya dapat digunakan pada materi sistem persamaan linear tiga variabel saja. Oleh karena itu, untuk penelitian selanjutnya disarankan untuk mencoba penerapan model pembelajaran Problem Based Learning pada materi atau pokok bahasan lain. 


\section{Daftar Pustaka}

Arikunto, Suharsimi, (2013). Dasar-dasar Evaluasi Pendidikan. Jakarta : Bumi Aksara.

Astuti, Rahardjo. (2011). Analisis Kesalahan Siswa dalam Menyelesaikan Soal Cerita Sistem Persamaan Lniear Dua Variabel Berdasarkan Langkah Penyelesaian Polya. Universitas Negeri Malang. Diambil dari http://ejurnal.unm.ac.id/ Febrian, F. (2016). T he Instruction To Overcome The Inert Knowledge Issue In Solving Mathematical Problem. Jurnal Gantang, 1(1), 16-25.

Hariyanto, Warsono. (2014). Pembelajaran Aktif. Jakarta: T Remaja Rosdakarya. Problem Based Learning (PBL) Pada Pembelajaran Matematika Siswa Kelas VIII Smp Negeri B. Srikaton Tahun Pelajaran 2015/2016. Sekolah Tinggi Keguruan dan Ilmu Pendidikan. Diambil dari http://ejurnal.stkip.ac.id/ Rusman. 2014. Model - Model Pembelajaran. Jakarta: PT Rajagrafindo Persada.

Silitonga, N., \& Febrian, F. (2016). Penyelesaian Masalah Bangun Datar Siswa Kelas Vii: Kesalahan Dan Kategorisasinya. Jurnal Gantang, 1(2), 57-68.

Sutikno Sobry . 2014. Metode dan Model Model Pembelajaran. Lombok: PT Holistica.

Sukardi. (2013). Metode Penelitian Pendidikan Tindakan Kelas:Implementasidan

Pengembangannya. Jakarta: Bumi Aksara.
Yusri, A. Y. (2018). Pengaruh Model Pembelajaran Problem Based Learning Terhadap Kemampuan Pemecahan Masalah Matematika Siswa Kelas Vii Di Smp Negeri Pangkajene. Mosharafa: Jurnal Pendidikan Matematika, 7(1), 51-62. 